\title{
Efficacy, Fruit Residues, and Soil Dissipation of the Herbicide Metolachlor in Processing Tomato
}

\author{
J.D. Gaynor, A.S. Hamill, and D.C. MacTavish \\ Agriculture Canada, Harrow, Ont. NOR 1G0, Canada \\ Additional index words. Acetanilide herbicide, Lycopersicon esculentum, eastern black nightshade, Solarium ptycanthum, \\ residue analysis
}

\begin{abstract}
Metolachlor was evaluated for annual grass and eastern black nightshade (Solarium ptycanthum Dun.) control in processing tomato (Lycopersicon esculentum Mill.). Metolachlor applied preplant incorporated provided excellent $(>\mathbf{8 8 \%}$ ) control of annual grasses and eastern black nightshade. The metolachlor, metribuzin plus trifluralin tank mix applied preplant and incorporated into the soil provided better annual grass and eastern black nightshade control than the metolachlor plus metribuzin tank mix in two of three years. Nonincorporated and posttransplant treatments of metolachlor provided good annual grass control but failed to control eastern black nightshade. Tomato yield in all herbicide treatments was similar to that from hand weeded controls. Metolachlor dissipated from the soil throughout the growing season so that at the time of harvest $<10 \%$ of that applied was recovered. Metolachlor residues in the fruit were hydrolyzed to deacylated (CGA 37913) or hydrolyzed conjugated (CGA 49751) metolachlor metabolizes. Analyses of extracts from treated fruits were found to be less than the detection limit of $50 \mathrm{ppb}$ in the whole fruit harvested from selected metolachlor treatments. Chemical names used: 2-chloro- $N$-(2-ethyl-6-methylphenyl)- $N$-(2-methoxy-1-methylethyl) acetamide (metolachlor); 2,6-dinitro- $N, N$-dipropyl-4-(trifluromethyl)benzenamine (trifluralin); 4-amino-6-(1,1-dimethylethyl)-3-(methylthio)-1,2,4-tlriazin-5(4H)-one (metribuzin); 2(2-ethyl-6-methylphenyl)amino-1-propanol (CGA 37913); 4-(2-ethyl-6-methylphenyl)-2-hydroxy-5-methyl-3-morphol. inone (CGA 49751).
\end{abstract}

Metolachlor is a selective herbicide registered for use in soybeans [Glycine max (L.) Merr], corn (Zea mays L.) and potato (Solarium tuberosum L.) primarily for the control of annual grasses and yellow nutsedge (Cyperus esculentus L.) (LeBaron et al., 1988). Field studies (Brown, 1983) have indicated no injury to processing tomato at herbicide rates up to $3.0 \mathrm{~kg} \cdot \mathrm{ha}^{-1}$. Trifluralin, metribuzin, and 3-amino-2,5-dichlorobenzoic acid (chloramben) are predominant herbicides used for control of annual grasses and broadleaf weeds in tomato (Ontario Ministry Agriculture Food, 1990). Except for chloramben, these herbicides lack efficacy for control of eastern black nightshade. Reregistration of chloramben is not being pursued in Canada or the United States.

Annual nightshade (Solarium spp.) species have been identified as an increasing problem in field crop production in Minnesota and other parts of North America (Bassett and Munro, 1985; Quakenbush and Andersen, 1984). Because currently registered herbicides do not adequately control nightshade, this species has been recognized as an increasing weed problem in processing tomato (Friesen, 1979). Infestations of as few as two nightshade plants per meter of row can reduce yield by $20 \%$ in transplanted tomatoes and $70 \%$ in field seeded tomatoes (Weaver et al., 1987). Eastern black nightshade is susceptible to metolachlor and, to a lesser extent, chloramben (Quakenbush and Andersen, 1985). Field trials in Ontario have shown good control of eastern black nightshade by metolachlor without injury to tomato (Brown, 1983; O'Sullivan, 1983). Metolachlor probably would replace chloramben if its registration was extended to tomato.

Various plant species detoxify metolachlor by dealkylation and hydroxylation followed by conjugation of these products to

Received for publication 18 Feb. 1992. Accepted for publication 15 June 1992. The gift of analytical standards was provided by Ciba Geigy Canada. The technical assistance of M. Whaley, R. Boose, and A. Labaj was greatly appreciated. The cost of publishing this paper was defrayed in part by the payment of page charges. Under postal regulations, this paper therefore must be hereby marked advertisement solely to indicate this fact. glutathione, homoglutathione, or carbohydrates (Fuerst, 1987; LeBaron et al., 1988). Based on metabolism studies with other crops, it is highly probable that acid hydrolysis of the tomato fruit would produce two major residues: the deacylated hydrolysis product (CGA 37913) of metolachlor and the cyclized compound (CGA 49751) of metolachlor.

The purpose of this research was to 1) determine the metolachlor rates and application methods best suited for eastern black nightshade control in transplanted tomatoes, 2) measure the rate of metolachlor disappearance in soil, and 3) establish the level of metabolize residue in the tomato fruit harvested from selected metolachlor treatments in support of a minor use registration.

\section{Materials and Methods}

Field site. Tomatoes (cultivar FM6203 grown in 1987 through 1989 and cultivar 9478 in 1990) were machine transplanted in $1.5 \times 8$-m plots in a Fox sandy loam soil (Hapludalf subgroup: $70 \%$ sand, $16 \%$ silt, $14 \%$ clay, $2.6 \%$ organic matter, $\mathrm{pH} 5.9$ ) on the dates listed in Table 1 . The single row treatments were arranged in a randomized block design with four replicates. Row width was $150 \mathrm{~cm}$ with $30 \mathrm{~cm}$ between plants. Herbicide treatments included various rates of metolachlor (from 1.5 to 3.0

Table 1. Planting and application times for pretransplant (Pre T), shallow preplant incorporated (S-ppi), directed postemergence (Dirpost), and late postemergence (Post 1 and Post 2) herbicide treatment of processing tomato from 1987 to 1990.

\begin{tabular}{lcccc}
\hline \hline & \multicolumn{4}{c}{ Year and date } \\
\cline { 2 - 5 } Operation & 1987 & 1988 & 1989 & 1990 \\
\hline Planting & 13 May & 16 May & 16 May & 23 May \\
S-ppi & 13 May & 12 May & 15 May & 15 May \\
Pre T & 13 May & 16 May & 15 May & 22 May \\
Dir post & 2 June & 27 May & 24 May & 1 June \\
Post 1 & 2 June & NT & 24 May & NT \\
Post 2 & 23 June & 20 June & 16 June & NT \\
\hline
\end{tabular}

NT $=$ no treatment. 
$\mathrm{kg} \cdot \mathrm{ha}^{-1}$ ) in combination with metribuzin at $0.375 \mathrm{~kg} \cdot \mathrm{ha}^{-1}$, and/ or trifluralin at $0.5 \mathrm{~kg} \cdot \mathrm{ha}^{-1}$. Chloramben was evaluated with metribuzin in 1 year. Preplant incorporated, pretransplant, directed, and late postemergence herbicide treatments were applied in 370 liters water/ha at $210 \mathrm{kPa}$ using a $\mathrm{CO}_{2}$-pressurized boom mounted on a modified garden tractor on the dates shown in Table 1. The herbicides were incorporated with a vibrating shank cultivator.

Yield and weed ratings. Yield for each treatment was calculated from tomato fruit weight harvested from a 2-m section of row. Tomatoes ( 1 to $2 \mathrm{~kg}$ ) for metolachlor residue analysis were harvested from selected treatments and stored at $-15 \mathrm{C}$. Annual grass and broadleaf control in the entire plot was visually assessed 60 to 70 days after transplanting using a scale of $\mathrm{O}$ (no control) to 100 (complete control) (Hamill et al., 1977). Herbicide injury to the crop was noted if present. All data were subjected to analysis of variance (ANOVA) within years; means for yields and weed control were separated by LSD $(P<0.05)$ test. Yield from the unweeded treatment was not included in the analysis because of the skewness associated with the data. Selected main effects were separated by contrast analysis.

Residue analysis. The frozen fruits were rinsed with tap water and homogenized before analysis. Frozen samples $(250 \mathrm{~g})$ from untreated and selected metolachlor treatments (identified by asterisk in Tables 2 to 3) were hydrolyzed in $230 \mathrm{ml} \mathrm{HCI}$ at 12 mol-liter ${ }^{-1}$ under reflux at $100 \mathrm{C}$ for $17 \mathrm{~h}$. The sample was cooled and the extract analyzed for CGA 37913 and CGA 49751 according to the procedure by Gaynor et al. (1992).

GC/MSD analysis. The tomato extracts were analysed on a HP 5890 gas chromatography with a HP 5870B mass selective detector (Hewlett-Packard Mississauga, Ont.) operated in selected ion mode. The extracts were injected onto a $30 \mathrm{~m} \times$ 0.25-mm Supelcowax 10 column having a film thickness of
$0.25 \mu \mathrm{m}$. Carrier and purge gas was prepurified He (99.995\%) at a flow rate of $30 \mathrm{ml} \cdot \mathrm{min}^{-1}$. Gas chromatography operating conditions have been reported by Gaynor et al. (1992).

Soil residues. Twenty soil cores of $2.5 \mathrm{~cm}$ diameter and 10 $\mathrm{cm}$ depth were composite within each plot at application and $0.5,1,2$, and 3 months from herbicide application. The soil samples were air-dried and stored at $-15 \mathrm{C}$ for analysis. A $40-$ g soil sample was extracted on a rotary shaker (New Brunswick Model V, New Brunswick, N.J.) with $100 \mathrm{ml}$ methanol for 1 h. The samples were filtered under suction through Whatman no. 1 filter paper, and the extracts were dried on a rotary evaporator at 40C. The residue was dissolved in an appropriate volume of 95 hexane :5 ethyl acetate $(\mathrm{v} / \mathrm{v})$ for analysis on a Varian $3400 \mathrm{GC}$ using a $\mathrm{N}$-specific thermionic sensitive detector. Metolachlor was separated on a $1.2 \mathrm{~m} \times 6.4 \mathrm{~mm}$ id. glass column packed with $10 \%$ DC-200 on Gas Chrom W, HP. Injector and column temperatures were $220 \mathrm{C}$ and detector temperature was 250C. Flow to the detector was $175 \mathrm{ml} \cdot \mathrm{min}^{-1}, \mathrm{H}_{2}$ flow rate was $4.5 \mathrm{ml} \cdot \mathrm{min}^{-1}$ and $\mathrm{He}$ carrier flow rate was $30 \mathrm{ml} \cdot \mathrm{min}^{-1} \mathrm{Re}$ covery of metolachlor from fortified soil averaged $80 \%$.

\section{Results and Discussion}

Yield and herbicide efficacy. Yields were lower in 1988 than in the other three years (Tables 2 and 3) because of drought in the early stages of crop development (Fig. 1). One irrigation (26 mm) was applied in June 1988; however, it was applied too late to maximize yield compared to the other 3 years when rainfall was sufficient during the growing season. Tomato yield in the herbicide treatments was similar to that in the hand-weeded controls. In 1990, yield was higher from treatments in which metolachlor was applied preplant incorporated with trifluralin and metribuzin than from treatments in which metolachlor was applied without incorporation $(P<0.01)$. However, in other

Table 2. Annual grass and broadleaf control, eastern black nightshade (NS) cover, and tomato yield with metribuzin (metr.), metolachlor (metol.), and chloramben (chlor.) herbicide combinations for
$1987 .{ }^{2}$

\begin{tabular}{|c|c|c|c|c|c|c|}
\hline \multirow[b]{2}{*}{ Treatment } & \multirow[b]{2}{*}{$\begin{array}{c}\text { Rate } \\
\left(\mathrm{kg} \cdot h \mathrm{a}^{-1}\right)\end{array}$} & \multirow[b]{2}{*}{$\begin{array}{c}\text { Application } \\
\text { time }^{\mathrm{y}}\end{array}$} & \multicolumn{2}{|c|}{ Control of } & \multirow{2}{*}{$\begin{array}{c}\text { NS } \\
\text { cover } \\
(\%)\end{array}$} & \multirow{2}{*}{$\begin{array}{c}\text { Tomato } \\
\text { fruit, } \\
\left(t \cdot h a^{-1}\right)\end{array}$} \\
\hline & & & $\begin{array}{c}\text { Grasses } \\
(\%)\end{array}$ & $\begin{array}{c}\text { Broadleaves } \\
(\%)\end{array}$ & & \\
\hline Hand weeded* & 0 & & 100 & 100 & 0 & 40.2 \\
\hline Not weeded & 0 & & 23 & 33 & 0 & 0.0 \\
\hline \multirow{16}{*}{$\begin{array}{l}\text { Metr. + metol. } \\
\text { Metr. + metol.* } \\
\text { Metr.; metol. } \\
\text { Metr.; metol. } \\
\text { Metr.; metol. } \\
\text { Metr.; metol. } \\
\text { Metr.; metol. } \\
\text { Metr.; metol.; chlor. } \\
\text { Metr.; metol.; chlor* } \\
\text { Metr.; metol. + chlor. } \\
\text { Metr.; metol.; chlor. } \\
\text { Metr.; metol.; chlor. } \\
\text { Metr.; chlor.; chlor } \\
\text { Metr.; chlor.; chlor } \\
\text { Metr.; chlor. }\end{array}$} & $0.375+1.5$ & S-ppi & 70 & 91 & 1 & 34.1 \\
\hline & $0.375+2.0$ & S-ppi & 92 & 92 & 1 & 42.7 \\
\hline & $0.375 ; 1.5$ & S-ppi;Pre T & 53 & 61 & 11 & 32.1 \\
\hline & $0.375 ; 2.0$ & S-ppi;Pre T & 63 & 86 & 3 & 34.1 \\
\hline & $0.375 ; 1.5$ & S-ppi;Dir post & 70 & 86 & 9 & 40.8 \\
\hline & $0.375 ; 2.0$ & S-ppi;Dir post & 70 & 85 & 8 & 37.9 \\
\hline & $0.375 ; 2.0$ & S-ppi;post 1 & 84 & 75 & 13 & 42.8 \\
\hline & $0.375 ; 1.5 ; 3.0$ & S-ppi;Pre T;post 1 & 54 & 83 & 8 & 42.1 \\
\hline & $0.375 ; 2.0 ; 3.0$ & S-ppi;Pre T;post 1 & 76 & 92 & 3 & 33.8 \\
\hline & $0.375 ; 1.5+3.0$ & S-ppi;post 1; & 77 & 86 & 5 & 38.6 \\
\hline & $0.375 ; 1.5 ; 3.0$ & S-ppi;Dir post;post 1 & 75 & 84 & 13 & 38.8 \\
\hline & $0.375 ; 2.0 ; 3.0$ & S-ppi;Dir post;post 1 & 81 & 88 & 10 & 40.2 \\
\hline & $0.375 ; 2.25 ; 2.25$ & S-ppi;post 1;post 2 & 60 & 81 & 13 & 31.1 \\
\hline & $0.375 ; 3.5 ; 2.25$ & S-ppi;post 1 ;post 2 & 80 & 83 & 10 & 29.4 \\
\hline & $0.375 ; 4.5$ & S-ppi;post 1 & 60 & 96 & 4 & 41.7 \\
\hline & & $\begin{array}{l}\operatorname{LSD}(P=0.05) \\
\operatorname{CV}(\%)\end{array}$ & $\begin{array}{l}21 \\
21\end{array}$ & $\begin{array}{l}13 \\
11\end{array}$ & $\begin{array}{l}\text { NS } \\
\text { NS }\end{array}$ & $\begin{array}{l}12.7 \\
23.7\end{array}$ \\
\hline
\end{tabular}

${ }^{2}$ Grass species were large crabgrass, barnyardgrass, and yellow foxtail; broadleaf species were redroot pigweed, common ragweed, common lambsquarters, and nightshade. Asterisk $\left({ }^{*}\right)$ denotes treatments selected for metolachlor residue analysis.

'See Table 1 for abbreviations. 

Table 3. Annual grass and broadleaf control, eastern black nightshade cover, and tomato yield with metribuzin, metolachlor, trifluralin (tri.),
and chloramben herbicide combinations for 1988,1989 , and $1990 .^{z}$

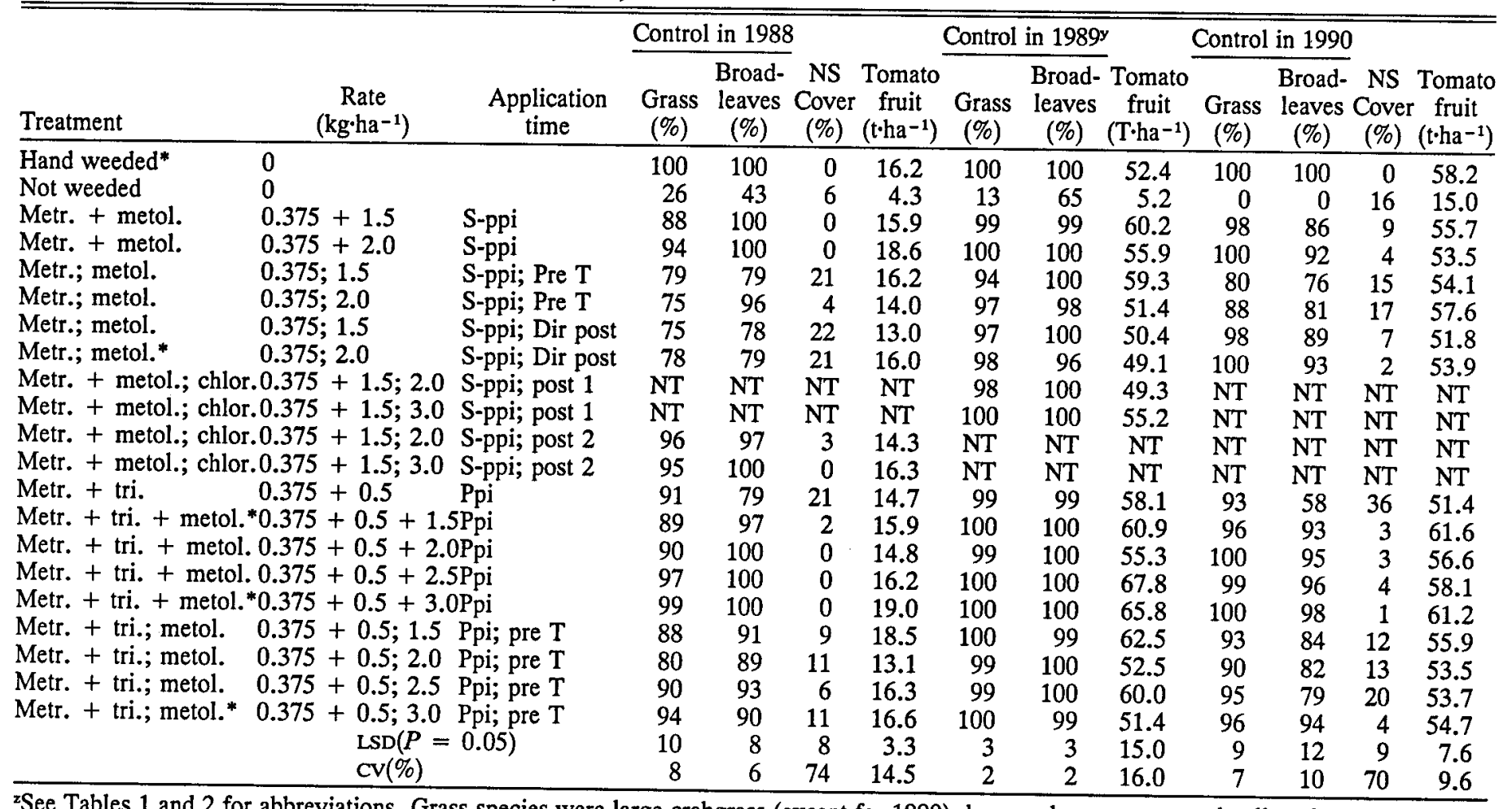

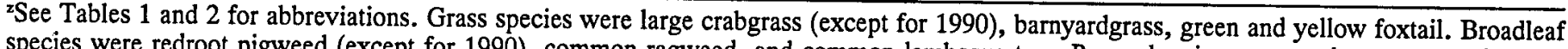
species were redroot pigweed (except for 1990), common ragweed, and common lambsquarters. Pennsylvania smartweed was present in 1989
and 1990 . Asterisk $\left({ }^{*}\right)$ denotes treatments selected for metolachlor residue analysis.

y No nightshade emerged in any of the treatments in 1989.

years, metolachlor applied with or without trifluralin provided no additional benefit in yield $(P>0.05$ in appropriate contrasts). Herbicide treatments were not injurious to tomato transplants in any of the trials.

The predominant grass species were large crabgrass (Digitaria sanguinalis L. Stop.), barnyardgrass (Echinochloa crusgalli L. Beauv.), green foxtail (Setaria viridis L. Beauv.), and yellow foxtail (Setaria glauca L. Beauv.). Green foxtail was absent from the trials in 1987 and crab grass was absent in 1990. Annual grass control was good to excellent (> 80\%) in all treatments in 1989 and 1990 (Table 3). Annual grass control was poor $(53 \%$ to $84 \%)$ in 1987 in treatments in which metolachlor was not incorporated (Table 2). Annual grass control was similar in all treatments where metolachlor was incorporated along with trifluralin or where metolachlor was applied pretransplant after trifluralin incorporation. When used alone, soil incorporation of metolachlor provided better control of the annual grasses than when metolachlor was not incorporated $(P<0.01)$, particularly in years when rainfall was limiting (Fig. 1).

The predominant broadleaf weeds were redroot pigweed (Amaranthus retroflexus L.), common ragweed (Ambrosia artemisiifolia L.), and common lambsquarters (Chenopodium album L.). Pennsylvania smartweed (Polygonum pensylvanicum L.) was present in 1989 and 1990, but pigweed was absent in 1990. Eastern black nightshade was present in all years but 1989. The area used for the 1989 trial had a history of eastern black nightshade infestation, but for reasons unexplainable by us, this weed species did not germinate in this trial even following a mid-June cultivation, which sometimes stimulates eastern black nightshade germination. Eastern black nightshade was absent in the nonweeded control plots in 1987, and in other years percentage of eastern black nightshade cover was low in this treatment because this weed does not appear to compete well with other weeds. Eastern black nightshade was present in other treatments where it was not controlled by the herbicides and competition from other broadleaf weeds was removed.

All combinations of the three herbicides (metolachlor, trifluralin, or chloramben) with metribuzin provided acceptable control of broadleaf weeds, however, only the preplant incorporated treatments with metolachlor provided adequate, consistent eastern black nightshade control $(P<0.01)$. Chloramben and metolachlor applied preemergence followed by irrigation soon after application provided excellent control (> 93\%) of four nightshade species in a field experiment (Ogg, 1986). Several nightshade species were found to be more susceptible to metolachlor than chloramben in nutrient solution (Quakenbush and Andersen, 1985). In our studies, single and split rates of chloramben were applied postemergence in 1987 with metribuzin. The single rate of chloramben at $4.5 \mathrm{~kg} \cdot \mathrm{ha}^{-1}$ provided $96 \%$ broadleaf weed control and the split application provided $81 \%$ to $83 \%$ broadleaf control, but the former reduced eastern black nightshade cover to $4 \%$ compared to $10 \%$ to $13 \%$ in the split application plots. Metolachlor applied postemergence or pretransplant failed to control nightshade adequately in all years in which eastern black nightshade was present. Pretransplant applications of metolachlor up to $3.0 \mathrm{~kg} \cdot \mathrm{ha}^{-1}$ did not provide adequate control of this weed species. Thus, for eastern black nightshade control, we recommend that metolachlor be preplant incorporated at $1.5 \mathrm{~kg} \cdot \mathrm{ha}^{-1}$ with metribuzin. Higher rates of metolachlor, during the period of this study, did not provide 


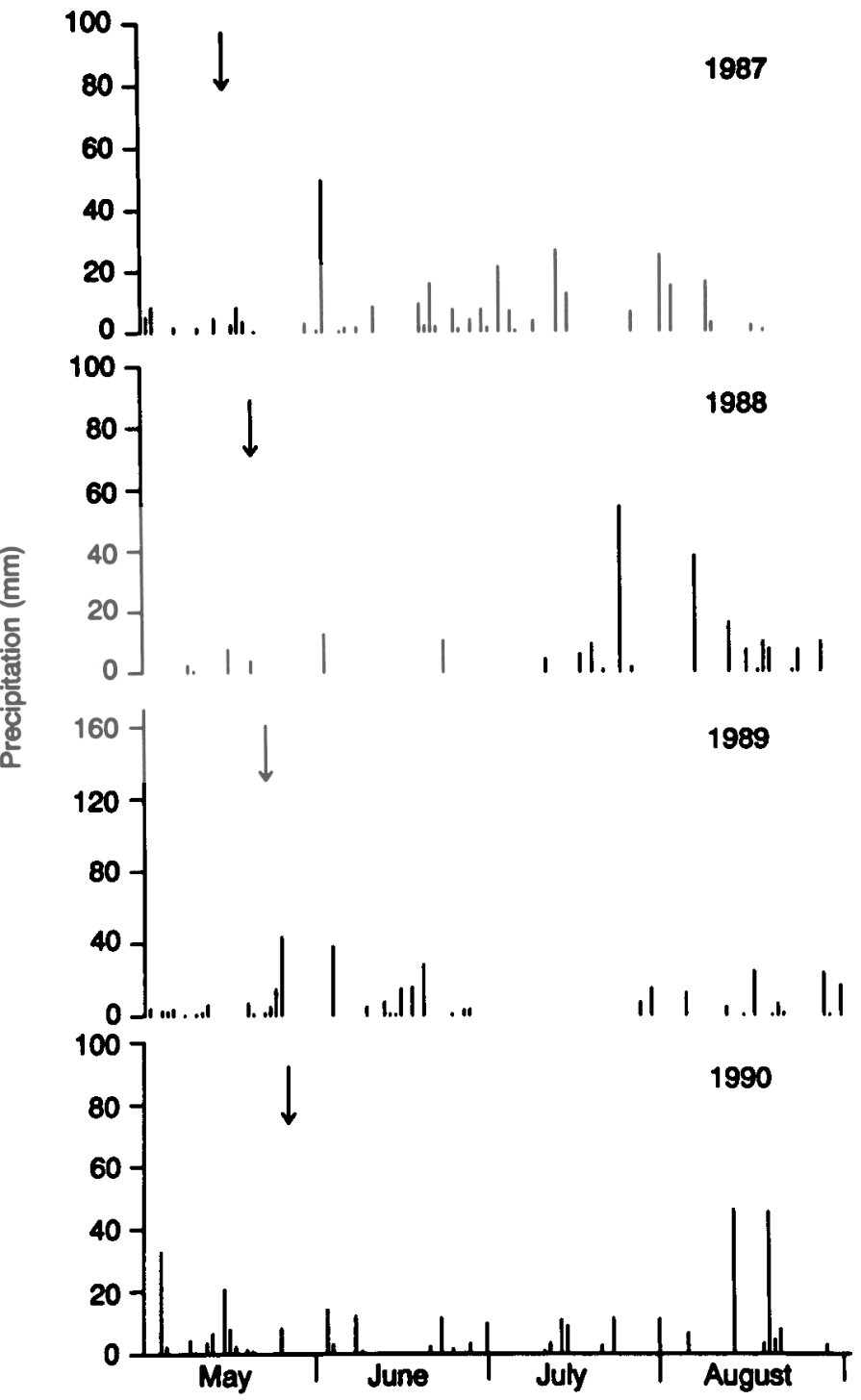

Fig. 1. Precipitation at Harrow for 1987, 1988, 1989, and 1990. Arrow denotes time of planting.

additional eastern black nightshade control. The inclusion of trifluralin with the low rate $\left(1.5 \mathrm{~kg} \cdot \mathrm{ha}^{-1}\right)$ of metolachlor plus metribuzin in the spray mixture may provide improved annual grass control in fields heavily infested with annual grasses.

Metolachlor residues in soil. Metolachlor that dissipated in soil from the tomato trial was well described by the first order rate equation, $\mathrm{C}=\mathrm{C}_{\mathrm{O}} \mathrm{e}^{-\mathrm{kt}}$, where $\mathrm{C}$ and $\mathrm{C}_{\mathrm{O}}$ are metolachlor concentration in soil at time $\mathrm{t}$ and time of application, respectively, and $\mathrm{k}$ is the first order rate constant (Table 4). After 40 days, residues in the soil decreased to $\approx 10 \%$ of that applied. Half-life, the time for metolachlor to dissipate to half the application rate, was calculated from the first order rate constant (Table 4). Incorporation of the herbicide did not affect the rate of metolachlor loss as denoted by similar half-lives among treatments (Table 4), probably because rainfall was received soon after application. Half-life of metolachlor is shorter at higher soil moisture content and temperature than in drier, cooler soil (Bouchard et al., 1982; Braverman et al., 1986; Zimdahl and Clark, 1982). In accordance with findings, metolachlor was more persistent (half-life 35 to 47 days) in 1988 than in 1989 (halflife 12 to 14 days), probably because of reduced biological activity at the lower soil moisture content (Fig. 1). Metolachlor
Table 4. Coefficient of determination $\left(R^{2}\right)$, first order rate constant (k), and half-life for metolachlor in Fox soil from selected herbicide treatments.

\begin{tabular}{|c|c|c|c|}
\hline $\begin{array}{l}\text { Metolachlor treatment } \\
\text { and rate } \mathrm{kg}^{\mathbf{z}} \mathrm{ha}^{-1}\end{array}$ & $\begin{array}{c}\text { Coefficient of } \\
\text { determination } \\
\left(R^{2}\right)\end{array}$ & $\begin{array}{l}\text { Rate constant } \\
(\mathrm{k})\end{array}$ & $\begin{array}{c}\text { Half-life } \\
\text { (days) }\end{array}$ \\
\hline \multicolumn{4}{|c|}{1988} \\
\hline $1.5 ; \mathrm{ppi}$ & $0.83^{* *}$ & $-0.0192 \pm 0.0018$ & 36 \\
\hline $3.0 ; \mathrm{ppi}$ & $0.74^{* *}$ & $-0.0167 \pm 0.0021$ & 42 \\
\hline $1.5 ;$ pre $\mathrm{T}$ & $0.57^{* *}$ & $-0.0165 \pm 0.0035$ & 42 \\
\hline 3.0; pre $\mathrm{T}$ & $0.55^{* *}$ & $-0.0162 \pm 0.0034$ & 43 \\
\hline $2.0 ;$ S-ppi & $0.81^{* *}$ & $-0.0200 \pm 0.0021$ & 35 \\
\hline 2.0; pre $\mathrm{T}$ & $0.53^{* *}$ & $-0.0146 \pm 0.0033$ & 47 \\
\hline \multicolumn{4}{|c|}{1989} \\
\hline 1.5; ppi & $0.85^{* *}$ & $-0.0559 \pm 0.0067$ & 12 \\
\hline 3.0; ppi & $0.85^{* *}$ & $-0.0522 \pm 0.0059$ & 13 \\
\hline $1.5 ;$ pre $\mathrm{T}$ & $0.90^{* *}$ & $-0.0497 \pm 0.0045$ & 14 \\
\hline 3.0; pre T & $0.79^{* *}$ & $-0.0490 \pm 0.0069$ & 14 \\
\hline $2.0 ;$ S-ppi & $0.89^{* *}$ & $-0.0536 \pm 0.0051$ & 13 \\
\hline 2.0: pre $\mathrm{T}$ & $0.85^{* *}$ & $-0.0481 \pm 0.0059$ & 14 \\
\hline
\end{tabular}

can leach into soil similar in organic matter and clay content to the Fox sandy loam (Bowman, 1988 and 1989; Huang and Frink, 1989; Obrigawitch et al., 1981; Peter and Weber, 1985; Van Biljon et al., 1988). Persistence was similar for metolachlor rates of 1.5 to $3.0 \mathrm{~kg} \cdot \mathrm{ha}^{-1}$ (Table 4).

Metolachlor residues in tomato. Fortification of tomato fruit extracts with CGA 37913 and CGA 49751 at 50, 100, and 200 ppb yielded recoveries of $87 \%$ to $96 \%$. Analysis of tomato fruit harvested from plots that received from 1.5 to $3.0 \mathrm{~kg}$ metolachlor/ha applied preplant incorporated, pretransplant, or postemergence failed to detect either of these metabolizes of metolachlor at $<50 \mathrm{ppb}$ (data not shown). Preliminary analysis of dichloromethane extracts of tomato harvested from plots treated with $3.0 \mathrm{~kg}$ metolachlor/ha detected no parent metolachlor $(<1$ $\mathrm{ppb}$ ) in tomato fruit. Neither CGA 37913 nor 4-(2-methyl-6ethylphenyl)-5-methylmorpholin-3-one (CGA 40919), the two major hydrolysis products (75\%) of metolachlor, was present in the mass spectral scan of hydrolyzed extracts.

Metolachlor applied pretransplant or preplant incorporated was effective in the control of annual grasses and eastern black nightshade. Its use in conjunction with other broadleaf control herbicides would replace chloramben in processing tomato production where eastern black nightshade is a problem. These results have contributed to the acceptance, by Agriculture Canada, for registration of metolachlor for eastern black nightshade control in processing tomato.

\section{Literature Cited}

Bassett, I.J. and D.B. Munro. 1985. The biology of Canadian weeds. 67. Solarium ptycanthum Dunn., S. nigrum L. and S. sarrachoides Sendt. Can. J. Plant Sci. 65:401-414.

Bouchard, D. C., T.L. Lavy, and D.B. Marx. 1982. Fate of metribuzin, metolachlor, and fluometuron in soil. Weed Sci. 30:629-632.

Bowman, B.T. 1988. Mobility and persistence of metolachlor and aldicarb in field lysimeters. J. Environ. Qual. 17:689-694.

Bowman, B.T. 1989. Mobility and persistence of the herbicides atrazine, metolachlor and terbuthylazine in Plainfield sand determined using field lysimeters. Environ. Toxicology Chem. 8:485491.

Braverman, M. P., T.L. Lavy, and C.J. Barnes. 1986. The degradation and bioactivity of metolachlor in the soil. Weed Sci. 34:479-484. 
Brown, R.H. 1983. Herbicide combinations for optimum weed control in transplanted processing tomatoes. Weed Abstr. 1983, 322433. (Abstr.)

Friesen, G.H. 1979. Weed interference in transplanted tomatoes (Lycopersicon esculentum). Weed Sci. 27:11-13.

Fuerst, E.P. 1987. Understanding the mode of action of the chloroacetamide and thiocarbamate herbicides. Weed Technol. 1:270-277.

Gaynor, J.D., D.C. MacTavish, and A.S. Hamill. 1992. GC/MSD detection of the metabolic residues of metolachlor in tomato fruit. Chromatographia 33:147-150.

Hamill, A. S., P.B. Marriage, and G. Friesen. 1977. A method for assessing herbicide performance in small plot experiments. Weed Sci. 25:386-389.

Huang, L.Q. and C.R. Frink. 1989. Distribution of atrazine, simazine, alachlor, and metolachlor in soil profiles in Connecticut. Bul. Environ. Contamination Toxicology 43:159-164.

LeBaron, H. M., J.E. McFarland, B.J. Simoneaux, and E. Ebert. 1988. Metolachlor, p. 335-382. In: P.C. Keamey and D.D. Kaufman (eds.). Herbicides: Chemistry, degradation, and mode of action. vol 3. Marcel Dekker, New York.

Obrigawitch, T, F.M. Hens, J.R. Abernathy, and J.R. Gipson. 1981. Adsorption, resorption, and mobility of metolachlor in soils. Weed Sci. 29:332-336.
Ogg, A.G. Jr. 1986. Variation in response of four nightshades (Solanum spp.) to herbicides. Weed Sci. 34:765-772.

Ontario Ministry of Agriculture and Food. 1990. Guide to Weed Control. Ont. Ministry Agr. Food Publ. 75.

O'Sullivan, J. 1983. Herbicides for nightshade (Solanum americanum, Mill) control in peppers and tomatoes. Weed Abstr. 1983,32:3287. (Abstr.)

Peter, C.J and J.B. Weber. 1985. Adsorption, mobility, and efficacy of alachlor and metolachlor as influenced by soil properties. Weed Sci. 33:874-881.

Quakenbush, L.S. and R.N. Andersen. 1984. Distribution and biology of two nightshades (Solanum spp.) in Minnesota. Weed Sci. 32:529533.

Quakenbush, L.S. and R.N. Andersen. 1985. Susceptibility of five species of the Solanum nigrum complex to herbicides. Weed Sci. 33:386-390.

Van Biljon, J.J., H.T. Groeneveld, and P.C. Nel. 1988. Leaching depth of metolachlor in a drift sand soil. Applied Plant Sci. 277-80.

Weaver, S. E., N. Smits, and C.S. Tan. 1987. Estimating yield losses of tomatoes (Lycopersicon esculentum) caused by nightshade (Solanum spp.) interference. Weed Sci. 35:163-168.

Zimdahl, R.L. and S.K. Clark. 1982. Degradation of three acetanilide herbicides in soil. Weed Sci. 30:545-548. 